\title{
Analysis of Determining Factors of Decision in Purchasing Toothpaste "Close Up" in Buleleng District
}

\author{
I Wayan Cipta ${ }^{1, *}$ Gede Wira Kusuma ${ }^{1}$ Made Amanda Dewanti ${ }^{1}$ Gede Putu Agus
}

Jana Susila ${ }^{1}$

\author{
${ }^{1}$ Department of Management, Universitas Pendidikan Ganesha, Singaraja, Indonesia \\ *Corresponding author. Email: wayan.cipta@undiksha.ac.id
}

\begin{abstract}
The increasing intensity of competition requires companies to always pay attention to the needs and desires of consumers and try to meet their consumer expectations by providing more satisfying services than their competitors. Therefore each company must always keep growing in order to be able to compete. In the face of competition, companies must implement appropriate policies in marketing their products. The rise of various brands of toothpaste in market is followed by several factors considered by consumers in making decisions. These factors in general are product quality, taste variants, product design, and motivation. The research used quantitative design with survey methods. The data was collected using questionnaire and interpreted using factor analysis. The results showed that (1) the factors considered by consumers in purchasing decisions for toothpaste close up were price, promotion, and family, and (2) the most dominant factor considered by consumers was the price with the highest eigenvalue of 5.779.
\end{abstract}

Keywords: Factor analysis, Family, Price, Promotion.

\section{INTRODUCTION}

The increasing intensity of competition requires companies to always pay attention to the needs and desires of their consumers and try to meet their expectations by providing more satisfying services than their competitors. Thus only high-quality companies can compete and dominate the market and every company must always keep growing to survive. In the face of competition, companies must implement appropriate policies in marketing their products. The globalization era driven by the development of science and technology has had an impact on economic and business strength which is characterized by very tight competition. To deal with this, each country is required to improve industrial sectors providing a major contribution in increasing national income so as to strengthen economic conditions to face the progressively immense competition.

Manufacturers in Indonesia release various brands of toothpaste circulating in the market to meet their consumer needs at economical prices, but with almost the same benefits in order to compete. Toothpaste brands in Indonesia currently include Pepsodent, Ciptadent, Formula, Close Up, and many others. Every company in the dental and oral care industry competes to gain market share by offering products expected to fulfil the needs and desires of their consumers. The high intensity of competition in this industry makes the consumers face several types of products with many variations, brands, packaging, and quality. One company that takes advantage of existing opportunities in toothpaste products is PT. Unilever Indonesia Tbk. by releasing one of its toothpaste brands, Close Up. It is one of Unilever's brands providing various advantages in which it has a more minty taste, in the gel form, many variants, and so on. Based on the Top Brand Award for the toothpaste category in 2018-2019, there are brands in the top four, namely Pepsodent, Close Up, Ciptadent, and Formula. Close Up is in the second place with its competitor, Pepsodent. In Top Brand Award, Close Up index in 2018 was $14.5 \%$ and in $201910.7 \%$, there was a decrease of $3.8 \%$. Probably many people still do not recognize Close Up so well that it has not been able to dominate the Indonesian toothpaste market share. Consumer behavior is the individual activities which are directly involved in obtaining and using goods and services, including the decision-making process in the preparation and determination of these activities [1]. In simple terms, consumer behavior refers to that shown by individuals in buying and using goods and services [2]. [3] stated that 
consumer behavior is the action directly involved in obtaining, consuming, and disposing a product or service, including the decision processes that precede and follow the action. Meanwhile [4] defined consumer behavior as the purchasing behavior of end consumers, both individuals and households purchasing products for personal consumption.

The rise of various brands of toothpaste in market is followed by several factors considered by consumers in making decisions. These factors in general are product quality, taste variants, product design, and motivation. Simultaneously, consumers are now more willing to purchase SB products [5] and are delighted to have SB lines available in stores in which they shop [6]. Several factors drive consumer willingness to purchase SB products: socio-demographic factors [7], [8], economic factors [9], and psychographic factors [10]-[12]. Sociodemographic factors include household income, the number of children in the household, gender, age, etc. Previous research showed that income and family size was strong determinants of store brand purchase behaviour [8], [10]. Economic factors are related to the economic cycle, whilst psychographic factors involve variables such as value consciousness, risk awareness, price-quality inferences, self-smart shopper perceptions, etc. Consumer purchasing decisions are made by individual and households end consumers who purchase goods and services for personal consumption [13], in the other hand, according to [14], it is the selection of one action from two or more alternatives. Purchasing decisions made by consumers are based on various and specific motives. The stronger the consumer's impulses and motives, the stronger the decision to buy a particular product [15], [16]. Therefore companies must encourage and motivate consumers to make purchases [17], [18].

\section{METHOD}

This study used quantitative data, i.e. data that can be calculated or in the form of numbers and primary data i.e. data obtained directly from the object under study. The data includes product, price, promotion, distribution channel, family, reference group, respondents' age, lifestyle, motivation, learning, belief who purchased and used toothpaste Close $U p$ in Buleleng District which was obtained from questionnaire distributed to respondents and then processed by researchers.

Since the number population of toothpaste Close $U p$ consumers is unknown, this study used a purposive sampling technique, i.e. a sampling technique with certain criteria. Those criteria are : (1) respondents are people who live or are domiciled in Buleleng District, (2) respondents are those who know about toothpaste Close $U p$ product, (3) respondents are those who have used Close $U p$ with a minimum purchase of 3 times, and (4) respondents are those who have watched Close $U p$ advertisements. As for the sample size, according to
Roscoe [19], the appropriate sample size in the study is between 30 to 500. Therefore, this study used 100 respondents in which they were Close $U p$ consumers in Buleleng District.

This study comprised literature research and field research for data collection. Literature research was conducted by obtaining data regarding Close $U p$ market share from top brand awards as well as theoretical basis from books and previous studies. As for field research, it was carried out by obtaining data through questionnaires distribution. Questionnaires were distributed to consumers who purchased and used Close $U p$ in Buleleng District. The questionnaire, as an ordinal data collection instrument, is an elaboration of variable indicators in which before being used to collect data in the field must first be tested for its validity and reliability. Validity refers to the extent to which the instrument can be used to measure what is intended to be measured, while reliability refers to the extent to which the measurement instrument can be trusted or reliable [20].

The data obtained was interpreted using factor analysis. It is used to determine the factors that consumers consider in their decision to purchase Close $U p$. Factor analysis is a set of procedures used to reduce and summarize data without losing important information and performed in several stages [21]: (1) formulating the problem, the factors considered by consumers in the decision to purchase Close Up and the data obtained were analyzed using a factor analysis model; (2) creating the correlation matrix, all data entered and processed will generate a correlation matrix. With the correlation matrix, certain variables that do not have a correlation with other variables can be identified hence they are removed from the analysis and thus they are separated from significant factors and cannot be used again. In this way there will be no continuous errors so that they can be overcome and tested for accuracy. To test the accuracy of the factor analysis model, Bartlett's Test of Sphericity can be used to confirm that the variables in the sample are correlated. The results of this test indicate whether the relationship between the variables is significant or not. Another useful statistic is the Kaiser Mayer Olkin (KMO) to measure sample feasibility. Factor analysis is considered feasible if the KMO value is at least 0.5 . This value is used to measure the degree of correlation between variables with MSA criteria $\geq 0.5$; (3) determining the number of factors, the variables are rearranged based on the correlation of the results of the steps in point two to determine the factors used to represent the data. To determine several factors that can be accepted empirically, it can be done based on the magnitude of the Eigenvalue of each factor that appears. The larger the Eigenvalue, the more representative the factor is to represent a group of variables. The selected factors are factors that have Eigenvalue $\geq 1$; (4) performing factor 
rotation. The result of factor simplification in the factor matrix shows the relationship between factors and individual variables, but in these factors there are many correlated variables that are difficult to interpret. By using factor matrix rotation, factor matrices are transformed into simpler matrices so that they are easy to interpret. In this study, varimax rotation was used; (5) performing factor interpretation. Factor interpretation is carried out by grouping variables having high factor loading into these factors. To interpret the results of this study, the factor loading is at least 0.5 . Variables having factor loading less than 0.5 is removed from the model; (6) determining the accuracy of the model. The last stage of factor analysis is to find out whether the model is able to explain well. Existing phenomena need to be tested using the Principal Component Analysis (PCA) technique, by looking at the residual amount between the observed correlation and the correlation produced using Statistic Package and Social Science (SPSS) 16.0 for Windows.

\section{RESULTS \& DISCUSSION}

Based on Table 1, it can be seen that the Kaiser Mayer Oklin (KMO) value is 0.746, thus fulfilling the requirements for factor analysis. In addition, factor analysis was appropriately used to analyze the data obtained because the results of the Barlett's Test of Sphericity showed a significant result of 0.000 . It means that the correlation matrix has a significant correlation with the number of factors, because the significant value is less than 0.05 .

Based on Table 2, it is shown that the KMO is 0.746 and Barlett's Test of Sphericity is 1117.552, which is significant 0.000 . The KMO and the Measure of Sampling Adequacy (MSA) value on all variables are already above 0.5 and the significance value is 0.000 hence these variables can be analyzed further.

Based on Table 3, it is shown that there are three factors with eigenvalue $>1$, namely factor 1 which has an eigenvalue of 5.779 with a variance value of $52.534 \%$, factor 2 which has an eigenvalue of 1.866 with a variance value of $16.963 \%$, and factor 3 which has an eigenvalue of 1.026 with a variance value of $9.327 \%$. Cumulative percentage of variance is $78.824 \%$, meaning that $78.824 \%$ of all existing factors can be explained by the three formed factors. In other words, these three factors are able to explain the effect of $78.824 \%$ on the decision to purchase Close Up.

Based on Table 4, we can determine what factors establish the new factor based on the highest factor loading in each component. Factor 1 consists of product, price, reference group, respondent's age, motivation, learning, and belief, because these factors have the highest factor loading in component 1 . Factor 2 consists of promotion, distribution channel, and lifestyle, because these factors have the highest factor loading in component 2. Factor 3 consists of family, because this factor has the highest factor loading in component 3.

Table 1. The value of Keiser Meyer Olkin (KMO) and Bartlett's Test

\begin{tabular}{|l|l|l|}
\hline \multicolumn{2}{|c|}{ KMO and Bartlett's Test } \\
\hline \multicolumn{2}{|c|}{ Kaiser-Meyer-Olkin Measure of Sampling Adequacy. } & .746 \\
\hline \multirow{2}{*}{ Bartlett's Test of Sphericity } & Approx. Chi-Square & 1117.552 \\
\cline { 2 - 3 } & $\mathrm{df}$ & 55 \\
\cline { 2 - 3 } & Sig. & .000 \\
\hline
\end{tabular}

Table 2. The value of Measure of Sampling Adequency (MSA)

\begin{tabular}{|c|c|c|c|}
\hline Variabel & KMO & Barlett's Test Of Sphericity & Measure Of Sampling Adequency \\
\hline $\mathrm{X} 1$ & \multirow{9}{*}{0,746} & \multirow{9}{*}{$\begin{array}{c}1117,552 \\
\text { Sig. } 0,000\end{array}$} & 0,863 \\
\hline$x 2$ & & & 0,762 \\
\hline X3 & & & 0,661 \\
\hline X4 & & & 0,705 \\
\hline$\times 5$ & & & 0,717 \\
\hline X6 & & & 0,877 \\
\hline X7 & & & 0,738 \\
\hline X8 & & & 0,612 \\
\hline X9 & & & 0,750 \\
\hline
\end{tabular}




\begin{tabular}{|c|c|c|c|}
\hline $\mathrm{X} 10$ & \multirow{2}{*}{$\mathrm{X} 11$} & & 0,740 \\
\cline { 1 - 1 } & & 0,655 \\
\hline
\end{tabular}

Table 3. Total Variance Explained

\begin{tabular}{|l|c|c|c|c|c|c|}
\hline \multirow{2}{*}{ Component } & \multicolumn{3}{|c|}{ Initial Eigenvalues } & \multicolumn{3}{c|}{ Extraction Sums of Squared Loading } \\
\cline { 2 - 7 } & Total & \% of Variance & Cumulative \% & Total & \% of Variance & Cumulative \% \\
\hline 1 & 5,779 & 52,534 & 52,534 & 5,779 & 52,534 & 52,534 \\
\hline 2 & 1,866 & 16,963 & 69,497 & 1,866 & 16,963 & 69,497 \\
\hline 3 & 1,026 & 9,327 & 78,824 & 1,026 & 9,327 & 78,824 \\
\hline 4 & 0,835 & 7,591 & 86,415 & & & \\
\hline 5 & 0,570 & 5,186 & 91,600 & & & \\
\hline 6 & 0,392 & 3,563 & 95,163 & & & \\
\hline 7 & 0,224 & 2,039 & 97,202 & & & \\
\hline 8 & 0,137 & 1,245 & 98,447 & & & \\
\hline 9 & 0,099 & 0,899 & 99,347 & & & \\
\hline 10 & 0,047 & 0,429 & 99,975 & & & \\
\hline 11 & 0,025 & 0,225 & 100,000 & & & \\
\hline
\end{tabular}

Table 4. Rotated Component Matrix

\begin{tabular}{|l|c|c|c|}
\hline \multirow{2}{*}{ Product } & \multicolumn{3}{|c|}{ Component } \\
\cline { 2 - 4 } & 1 & 2 & 3 \\
\hline Price & 0,731 & 0,552 & 0,122 \\
\hline Promotion & 0,905 & 0,168 & 0,161 \\
\hline Distribution channel & 0,215 & 0,756 & $-0,418$ \\
\hline Family & 0,570 & 0,575 & 0,350 \\
\hline Reference group & 0,142 & 0,005 & 0,884 \\
\hline Respondent's age & 0,634 & 0,241 & 0,483 \\
\hline Lifestyle & 0,719 & $-0,017$ & 0,382 \\
\hline Motivation & 0,005 & 0,752 & 0,150 \\
\hline Learning & 0,841 & $-0,015$ & 0,323 \\
\hline Belief & 0,759 & 0,476 & $-0,310$ \\
\hline
\end{tabular}

\section{CONCLUSION}

Based on research conducted regarding the factors that determine the decision to purchase Close $U p$, there are several conclusions: (1) the price factor with variance explained of $52.534 \%$ with factors consisting of: price with factor loading of 0.905 , belief with factor loading of 0.902 , motivation with a factor loading of 0.841 , learning with a factor loading of 0.759 , products with a factor loading of 0.731 , respondents age with a factor loading of 0.719 , reference group with a factor loading of 0.634 ;
(2) promotion factor with explained variance of $16.963 \%$ with factors consisting of: promotion with factor loading of 0.756 , lifestyle with factor loading of 0.752 , distribution channel with factor loading of 0.575 ; (3) the family factor with explained variance of $9.327 \%$ with a factor loading of 0.884 . The most dominant factor considered by consumers in purchasing toothpaste Close $U p$ is the price, because it has an eigenvalue of 5.779 and factor loading of 0.905 . 


\section{REFERENCES}

[1] B. Swastha and Irawan, Manajemen Pemasaran Modern. Yogyakarta: Liberty, 2002.

[2] J. P. Peter and J. C. Olson, Consumer Behavior and Marketing Strategy. 4th Edition. Damos, $S$. (penerjemah). Perilaku Konsumen dan Strategi Pemasaran Jilid 2. Jakarta: Erlangga, 2000.

[3] J. . Engel, R. . Blackwell, and P. W. Minard, Perilaku Konsumen. Jakarta: Binarupa Aksara, 2000.

[4] P. Kotler and K. L. Keller, Manajemen Pemasaran, Edisi Kedua Belas Jilid I. Jakarta: iNDEKS, 2007.

[5] PLMA, "Store brands and the recession," 2009. [Online]. Available: www.plma.com/PLMA_Store_Brands_and_the_ Recession.pdf.

[6] A. S. Binninger, "Exploring the relationships between retail brands and consumer store loyalty," Int. J. Retail Distrib. Manag., vol. 36, no. 2, pp. 94110, 2008.

[7] G. Baltas and C. Argouslidis, "Consumer characteristics and demand for store brand," Int. J. Retail Distrib. Manag., vol. 3, no. 5, pp. 328-341, 2007.

[8] E. Martínez and T. Montaner, "Characterisation of Spanish store brand consumers," Int. J. Retail Distrib. Manag., vol. 36, no. 6, pp. 477-493, 2008.

[9] L. Lamey, B. Deleersnyder, M. G. Dekimpe, and J. B. E. M. Steenkamp, "How business cycles contribute to private-label success: evidence from the US and Europe," J. Mark., vol. 71, no. 1, pp. 1$15,2007$.

[10] S. Burton, D. Lichtenstein, R. Netemeyer, and J. Garretson, "A scale for measuring attitude toward private label products and an examination of its psychological and behavioral correlates," J. Acad. Mark. Sci., vol. 26, no. 4, pp. 293-306, 1998.

[11] J. A. Garretson, D. Fisher, and S. Burton, "Antecedents of private label attitude and national brand promotion attitude: similarities and differences," J. Retail., vol. 78, no. 2, pp. 91-99, 2002.

[12] B. Jin and Y. G. Suh, "Integrating effect of consumer perception factors in predicting private brand purchase in a Korean discount store context," J. Consum. Mark., vol. 22, no. 2, pp. 62-71, 2005.

[13] P. Kotler, Manajemen Pemasaran I, Edisi Ketiga Belas. Jakarta: Erlangga, 2009.

[14] F. Tjiptono, Strategi Pemasaran. Yogyakarta: Andi, 2011.

[15] H. H. Chang and H. W. Wang, "The moderating effect of customer perceived value on online shopping behaviour," Online Inf. Rev., vol. 35, no. 3, pp. 333-359, 2011.

[16] F. Bai and Y. Qin, "Implementation of Relationship Marketing and CRM : How to Become a CustomerFocused Organization," J. Bus. Econ. Policy, vol. 3, no. 2, pp. 112-124, 2016.

[17] F. M. Diallo, J. L. Chandon, G. Cliquet, and J. Philippe, "Factors influencing consumer behaviour towards store brands: evidence from the French market," Int. J. Retail Distrib. Manag., vol. 41, no. 6, pp. 422-441, 2013.

[18] K. B. Monroe, Pricing: Making Profitable Decisions, 3 rd ed. New York: McGraw-Hill, 2002.

[19] U. Sekaran, Research Methods for Business. 4th Edition. Kwan, M.Y. (penerjemah). Metodologi Penelitian Untuk Bisnis. Buku 1. Jakarta: Salemba Empat, 2006.

[20] Sugiyono, Metode Penelitian Bisnis (Pendekatan Kuantitatif, Kualitatif dan R\&D). Bandung: Alfabeta.

[21] S. Santoso, SPSS Versi 11.5, Mengatasi Berbagai Masalah Statistik Dengan SPSS, Edisi Kelima. Jakarta: PT. Elex Media Komputido, 2004. 